\title{
DEGRADABILITAS NUTRIEN RANSUM YANG DIFORMULASI BERDASARKAN SISTEM PROTEIN TERCERNA DI INTESTINUM PADA SAPI PERAH DENGAN PAKAN BASAL JERAMI PADI SECARA IN SACCO
}

\author{
L.K. Nuswantara ${ }^{1}$, M. Soejono ${ }^{2}$, R. Utomo ${ }^{2}$, B.P. Widyobroto ${ }^{2}$ dan H. Hartadi ${ }^{2}$
}

\section{INTISARI}

Penelitian ini bertujuan untuk mengetahui degradasi nutrien (BK, BO, dan PK) pada sapi Peranakan Friesian Holstein ( $\mathrm{PFH}$ ) yang diberi ransum berpakan basal jerami padi yang diformulasi berdasarkan protein tercerna di intestinum (PDI). Manfaat dari penelitian adalah memberikan informasi tentang sistem evaluasi protein baru untuk meningkatkan efisiensi penggunaan nutrien pada ruminansia. Penelitian dilaksanakan di Jurusan Nutrisi dan Makanan Ternak Fakultas Peternakan Universitas Gadjah Mada. Penelitian menggunakan 6 ekor sapi PFH tidak berproduksi yang difistula rumennya dan berumur 2,5 sampai 3 tahun dengan bobot badan 250 - $300 \mathrm{~kg}$. Ransum yang digunakan adalah ransum dengan prekursor nitrogen tinggi (PDIN), ransum dengan prekursor energi tinggi (PDIE) dan ransum dengan prekursor nitrogen dan energi seimbang (PDIS). Variabel yang diamati meliputi degradasi bahan kering, bahan organik dan protein kasar ransum. Data yang diperoleh dianalisis variansi berdasar rancangan acak lengkap, dan jika terdapat perbedaan pengaruh perlakuan dilanjutkan Duncan's New Multiple Range Test. Hasil penelitian menunjukkan bahwa rata-rata degradasi bahan kering (DT BK), bahan organik (DT BO) dan protein kasar (DT PK) pada sapi PFH yang diberi ransum PDIN $(55,75 ; 56,44$ dan $73,50 \%)$ nyata lebih tinggi $(\mathrm{P}<0,05)$ dibanding sapi $\mathrm{PFH}$ yang diberi ransum $\mathrm{PDIS}(45,42 ; 49,47$ dan $62,8 \%$ ) dan PDIE $(44,72 ; 45,11$ dan 49,57\%). Degradasi teori nutrien (BK, BO dan PK) pada sapi $\mathrm{PFH}$ yang diberi ransum PDIS nyata lebih tinggi $(\mathrm{P}<0,05)$ dibanding yang diberi ransum PDIE.

(Kata kunci: In sacco, Bahan kering, Bahan organik, Protein kasar, PDIN, PDIE, PDIS, Jerami padi)

Buletin Peternakan 30 (4): 185 - 197, 2006

${ }^{1}$ Fakultas Peternakan Universitas Diponegoro, Semarang

${ }^{2}$ Fakultas Peternakan Universitas Gadjah Mada, Yogyakarta 


\title{
IN SACCO NUTRIENT DEGRADABILITY OF RATIONS FORMULATED BASED ON DEGRADABLE PROTEIN FED TO DAIRY CATTLE RECEIVING RICE STRAW AS THE BASAL DIET
}

\begin{abstract}
A research was conducted to determine the nutrients (dry matter, organic matter and crude protein) degradabilities of ration for Friesian Holstein crossbred cattle (PFH) fed with rice straw as basal diet which was formulated based on degradable protein in the small intestine system. The benefit of this research is to give information regarding protein evaluation system to increase nutrient efficiency for ruminants. The research was conducted at Department of Animal Nutrition and Feed Science, Faculty of Animal Science Gadjah Mada University. Using six rumen fistulated PFH of 2,5 - 3 years old with the body weight ranging from 250 to $300 \mathrm{~kg}$. The rations being used were ration with high nitrogen precursor (PDIN), ration with high energy precursor (PDIE) and ration with balanced nitrogen and energy (PDIS). Variables observed were degradabilities of dry matter, organic matter, and crude protein in the rations. Collected data were analyzed statistically with analysis of variances and Duncan's new Multiple Range Test. The result showed that the average degradabilities of dry matter (DT DM), organic matter (DT OM) and crude protein (DT CP) with PDIN ration $(55,75 ; 56,44$ and $73,50 \%)$ were higher $(\mathrm{P}<0,05)$ than PDIS ration $(45,42 ; 49,47$ and $62,8 \%)$ and PDIE ration $(44,72 ; 45,11$ and $49,57 \%)$. Nutrient degradabilities the ration with PDIS ration was higher $(\mathrm{P}<0,05)$ than $\mathrm{PDIE}$ ration.
\end{abstract}

(Key words: In sacco, Dry matter, Organic matter, Crude protein, PDIN, PDIE, PDIS, Rice straw)

\section{Pendahuluan}

Kecernaan adalah banyaknya pakan yang dapat dicerna di dalam alat pencernaan, dan dinyatakan dalam bahan kering serta apabila dinyatakan dalam persentase disebut koefisien cerna (Ørskov, 1992). Manfaat bahan pakan ditentukan oleh kecernaannya dan jumlah nutrien yang dapat diabsorbsi di dalam saluran pencernaan serta metabolismenya (McDonald et al., 1988).

Penggunaan jerami sebagai pakan ternak pada umumnya memiliki beberapa kekurangan di antaranya adalah kandungan protein kasarnya yang rendah dan kecernaan serta palatabilitasnya juga rendah. Keceranaan bahan kering (KcBK) dan kecernaan bahan organik (KcBO) jerami padi menurut Sutrisno (2002) sebesar 40,71 dan $38,54 \%$, nilai tersebut lebih rendah dibanding hasil penelitian Utomo (2001), yang melaporkan $\mathrm{KcBK}$ dan $\mathrm{KcBO}$ jerami padi pada sapi peranakan ongole (PO) sebesar 45,6 dan $39,13 \%$. Pemanfaatan jerami padi sebagai ransom basal harus diberi suplementasi dengan zat-zat pakan tambahan, terutama protein yang disebabkan rendahnya kandungan $\mathrm{N}$ jerami padi dan hampir seluruhnya terikat dengan bagian yang tak tercerna.

Suplementasi bahan pakan baik sumber protein maupun sumber energi pada ternak yang diberi pakan basal jerami padi yang pernah dilakukan hanya sebatas pada pemenuhan kebutuhan nutrien bagi mikrobia rumen agar kecernaan jerami padi meningkat. Aplikasi teknologi formulasi ransum yang seimbang dengan menerapkan sistem PDI (Protein truly Digestible in the small Intestine) diharapkan dapat memberikan produksi mikrobia rumen yang optimal (pelepasan prekursor $\mathrm{N}$ dan kerangka karbon yang sinkron) dan akhirnya kecernaan jerami padi di dalam rumen menjadi meningkat serta 
pasokan nutrien di intestinum untuk inang menjadi meningkat pula. Oleh sebab itu nilai manfaat suatu bahan pakan perlu determinasi dengan percobaan kecernaan. Pengukuran kecernaan dapat dilakukan dengan metode, in vitro, in sacco, dan in vivo.

Teknik in sacco (kantong nilon) dipergunakan untuk mengukur degradabilitas nutrien dalam rumen. Ørskov (1992) mendefinisikan laju degradasi sebagai jumlah pakan yang dapat dicerna per unit waktu. Penggunaan teknik ini sangat membantu dalam penentuan laju dan besarnya degradasi oleh mikrobia. Beberapa kelebihan dari metode in sacco adalah banyak digunakan karena sederhana dan hanya menggunakan beberapa ekor ternak berfistula (Soejono, 1990), dapat digunakan untuk menghitung kecepatan degradasi dalam rumen dan beberapa sampel dapat diinkubasikan dalam waktu bersamaan (Widyobroto et al., 1995), lebih praktis dan cepat (Leng, 1980), sangat membantu dalam menentukan laju dan besarnya degradasi oleh mikrobia rumen (Mehrez dan Ørskov, 1977), serta nilai degradasi dan tingkat degradasi bahan pakan dapat dengan cepat diketahui, pakan secara langsung diinkubasikan pada lingkungan rumen ternak (Ørskov dan Mc Donald, 1979). Kelemahan metode in sacco adalah pengukuran degradasi hanya pada satu bagian alat pencernaan sehingga hasil yang diperoleh kurang teliti dibanding in vivo (Ørskov, 1992).

Berdasarkan uraian di atas perlu dilakukan penelitian dengan tujuan untuk mengetahui degradasi bahan kering, bahan organik dan protein kasar ransum yang diformulasi berdasarkan sistem protein tercerna di intestinum dengan pakan basal jerami padi.

\section{Materi Dan Metode}

Penelitian dilakukan di Laboratorium Ilmu Makanan Ternak Jurusan Nutrisi dan Makanan Ternak Fakultas Peternakan Universitas Gadjah Mada Yogyakarta.
Penelitian ini berlangsung selama 4 minggu. Penelitian diharapkan akan memberikan gambaran penggunaan pakan basal jerami padi sebagai pakan basal yang diformulasi dengan sistem protein tercerna di intestinum terhadap efisiensi penggunaan nutrien yang akan dilihat dari aspek degradabilitas nutriennya yaitu bahan kering (BK), bahan organik (BO), dan protein kasar(PK).

Penelitian ini menggunakan 6 ekor sapi perah (PFH) tidak berproduksi yang difistula pada bagian rumennya, berumur 2,5 3,0 tahun dengan berat badan $250-300 \mathrm{~kg}$. Sampel ransum yang digunakan dalam penelitian adalah ransum yang diformulasi dengan prekursor nitrogen tinggi (PDIN), ransum prekursor energi tinggi (PDIE) dan ransum prekursor nitrogen dan energi seimbang (PDIS) dengan pakan basal jerami padi. Bahan pakan konsentrat yang digunakan adalah bahan pakan konsentrat yang tersedia di Yogyakarta dan sekitarnya (10 bahan pakan) berdasarkan perhitungan kembali dari tabel komposisi kimia (Hartadi, dkk., 1997) dan hasil nilai degradasi protein (Widyobroto et al., 1997). Rumus perhitungan nilai PDI menurut Jarrige (1989).

Bahan pakan basal dan bahan pakan konsentrat diformulasikan dengan sistem PDI. Kandungan energi dan protein ransum disusun sedemikian rupa sehingga didapat kandungan yang iso protein dan iso energi, sedangkan kandungan PDI disusun sedemikian rupa sehingga terdapat tiga macam ransum dengan kandungan PDI yang berbeda yaitu ransum PDIN (prekursor $\mathrm{N}$ tinggi), ransum PDIE (prekursor energi tinggi), dan ransum PDIS (mengandung prekursor $\mathrm{N}$ dan $\mathrm{E}$ yang seimbang). Komposisi kimia ransum penelitian disajikan pada Tabel 1 dan 2 .

Pengukuran degradasi protein, BK, dan BO dengan metode in sacco dilaksanakan menggunakan metode standar (Soejono dkk., 1998). Sampel pakan digiling menggunakan willey mill dengan ukuran diameter ayakan $2 \mathrm{~mm}$. Kantong nilon yang digunakan mempunyai porositas $46 \mathrm{~m}$, dimensi bagian. 
Tabel 1. Komposisi formula ransum (Feed formulated of ration)

\begin{tabular}{|c|c|c|c|c|}
\hline No & $\begin{array}{l}\text { Bahan Pakan } \\
\text { (Feed ingredient) }\end{array}$ & $\begin{array}{c}\text { Ransum } \\
\text { (Ration) } \\
\text { PDIN }\end{array}$ & $\begin{array}{c}\text { Ransum } \\
\text { (Ration) } \\
\text { PDIE }\end{array}$ & $\begin{array}{c}\text { Ransum } \\
\text { (Ration) } \\
\text { PDIS }\end{array}$ \\
\hline & & \multicolumn{3}{|c|}{ - } \\
\hline 1. & Bekatul (Rice bran) & 4,02 & 1,80 & 1,00 \\
\hline 2. & Onggok (Cassava pomace) & 16,50 & 2,00 & 2,65 \\
\hline 3. & Cassava (Cassava) & 0,00 & 2,00 & 0,00 \\
\hline 4. & Kulit biji Jagung (Corn hulls) & 5,52 & 12,00 & 12,35 \\
\hline 5. & Pollard (Wheat bran) & 7,02 & 0,00 & 1,90 \\
\hline 6. & Kulit biji kopi (Coffee hulls) & 3,00 & 9,00 & 11,00 \\
\hline 7. & $\begin{array}{l}\text { Bungkil kedelai terproteksi } \\
\text { (Protected of soybean meal) }\end{array}$ & 1,50 & 8,00 & 12,90 \\
\hline 8. & Bungkil kelapa ( Coconut meal) & 0,00 & 5,00 & 0,00 \\
\hline 9. & Bungkil kapok (Kapok seed meal) & 7,98 & 0,00 & 0,50 \\
\hline 10. & Bungkil kedelai (Soybean meal) & 1,5 & 4,00 & 0,40 \\
\hline 11. & Urea & 1,98 & 0,00 & 1,10 \\
\hline 12. & Jagung (Corn) & 10,62 & 10,60 & 16,20 \\
\hline 13. & Tepung ikan (Fish meal) & 0,00 & 3,60 & 0,00 \\
\hline 14. & Mollases (Mollases) & 0,00 & 2,00 & 0,00 \\
\hline 15. & Mineral (Mineral) & 0,36 & 0,00 & 0,00 \\
\hline 16 & Jerami padi (Rice staw) & 40,00 & 40,00 & 40,00 \\
\hline
\end{tabular}

dalam $6 \times 11 \mathrm{~cm}$, diisi dengan sampel pakan yang akan diuji $(3 \mathrm{~g})$, ditautkan dengan tali nilon pada alat pemberat $(675 \mathrm{~g})$, diinkubasikan dalam rumen selama 2, 4, 8, 16, 24 dan 48 jam, setiap titik inkubasi diulang sebanyak 6 kali. Kantong diambil sesuai dengan waktu inkubasi, dicuci dengan air kran dingin yang mengalir perlahan-lahan, kemudian dicuci dengan mesin cuci selama 9 menit dengan air selalu mengalir. Residu pakan setelah inkubasi dikeringkan pada suhu $60^{\circ} \mathrm{C}$ sampai berat konstan, kemudian masingmasing ditimbang residunya untuk menghitung kehilangan $\mathrm{BK}$ dan dilanjutkan analisis $\mathrm{BK}, \mathrm{BO}$, dan $\mathrm{PK}$ dengan metode AOAC (1975).

Degradasi BK, BO, dan PK, di dalam rumen dihitung dengan persamaan eksponensial $\mathrm{p}=\mathrm{a}+\mathrm{b}\left(1-\mathrm{e}^{-\mathrm{ct}}\right)$ (Ørskov dan Mc Donald, 1979), dengan hipotesis bahwa laju kecernaan BO dan PK (kd) konstan terhadap waktu.

$\mathrm{P}=$ bahan yang hilang pada waktu
$\mathrm{a}=$ fraksi mudah larut
$\mathrm{b}=$ fraksi potensial untuk terdegradasi
$\mathrm{c}=$ laju degradasi dari fraksi $\mathrm{b}$
$\mathrm{Kp}=$ laju partikel pakan keluar rumen (dengan $\mathrm{kp}=6 \%$ )

$$
\mathrm{DT}=\mathrm{a}+(\mathbf{b} \times \mathbf{c} / \mathrm{c}+\mathrm{kp})
$$

Fase lag $(\mathrm{L})$ dihitung dengan model $\mathrm{p}=\mathrm{a}$ untuk $\left.\mathrm{t}<\mathrm{t} 0, \mathrm{p}=\mathrm{a}+\mathrm{b}\left(1-\mathrm{e}^{-\mathrm{et}(\mathrm{t}-\mathrm{t}) \mathrm{t}}\right)\right)$ untuk $\mathrm{t}>$ to (Dhanoa, 1988), dimana perpotongan waktu awal pada kurve, $\mathrm{a}+\mathrm{b}$ merupakan asimtot dari kurve dan mencerminkan material yang terdegradasi jika telah ditentukan, c adalah konstante tingkat degradasi dan $\mathrm{p}$ adalah kehilangan karena terdegradasi pada waktu tertentu $(t)$. 
Tabel 2. Komposisi kimia ransum (Chemical composition of ration)

\begin{tabular}{|c|c|c|c|c|}
\hline & \multirow{2}{*}{$\begin{array}{c}\text { Komposisi kimia } \\
\text { (Composition of ration) } \\
\end{array}$} & \multicolumn{3}{|c|}{ Ransum (Ration) } \\
\hline & & PDIN & PDIE & PDIS \\
\hline \multicolumn{2}{|c|}{ Bahan kering" (Dry matter) } & 88,40 & 88,23 & 85,93 \\
\hline \multicolumn{2}{|c|}{$\mathrm{Abu}^{\mathrm{a}}($ Ash $)$} & 9,93 & 10,87 & 9,92 \\
\hline \multicolumn{2}{|c|}{ Lemak kasar (Extract ether) } & 3,02 & 2,93 & 2,71 \\
\hline \multicolumn{2}{|c|}{ Protein kasar ${ }^{a}$ (Crude protein) } & 18,40 & 18,05 & 18,20 \\
\hline \multicolumn{2}{|c|}{ Serat kasar (Crude fiber) } & 20,29 & 19,00 & 19,79 \\
\hline \multicolumn{2}{|c|}{$\begin{array}{l}\mathrm{TDN}^{\mathrm{b}} \text { (Total digestible nutrients) } \\
\mathrm{PDIN}^{\mathrm{c}}\end{array}$} & 60,51 & 60,94 & 61,17 \\
\hline \multirow{2}{*}{\multicolumn{2}{|c|}{$\begin{array}{l}\text { PDIN }^{c} \\
\text { PDIE }^{c}\end{array}$}} & 14,27 & 11,84 & 11,98 \\
\hline & & 9,50 & 12,50 & 11,90 \\
\hline \multicolumn{2}{|c|}{$\mathrm{NDF}^{a}$ (Neutral detergent fiber) } & 82,08 & 74,28 & 77,22 \\
\hline \multicolumn{2}{|c|}{$\mathrm{ADF}^{\mathrm{a}}$ (Acid detergent fiber) } & 31,03 & 32,16 & 33,74 \\
\hline \multicolumn{2}{|c|}{ Hemiselulosa } & 51,05 & 42,12 & 43,48 \\
\hline \multirow[t]{3}{*}{ Sumber: } & \multicolumn{4}{|c|}{ a Analisis proksimat (Proximat analized) } \\
\hline & \multirow{2}{*}{\multicolumn{4}{|c|}{$\begin{array}{l}\text { b Hasil perhitungan menurut Jarrige (1989) (Calculated with Jarrige formula } \\
(1989)) \\
\text { c Hasil perhitungan menurut Hartadi dkk., (1997) (Calculated with formula } \\
\text { Hartadi et al. (1997)) }\end{array}$}} \\
\hline & & & & \\
\hline PDIN & \multicolumn{4}{|c|}{$\begin{array}{l}\text { Protein digestible in the small intestine supplied by rumen undegraded dietary } \\
\text { protein and by microbial protein from rumen degraded protein }\end{array}$} \\
\hline PDIE & \multicolumn{4}{|c|}{$\begin{array}{l}\text { Protein digestible in the small intestine supplied by rumen undegraded dietary } \\
\text { protein and by microbial protein from rumen fermented organic matter }\end{array}$} \\
\hline
\end{tabular}

Nilai degradasi BK, BO, dan PK dianalisis variansi dan bila terdapat pengaruh nyata antar perlakuan dilanjutkan dengan uji DMRT menurutAstuti(1981).

\section{Hasil dan Pembahasan}

\section{Degradasi bahan kering ransum perlakuan secara in sacco}

Kinetik degradasi bahan kering sampel ransum penelitian (PDIN, PDIE dan PDIS) disajikan dalam Gambar 1. Data tersebut merupakan nilai rata-rata dari 6 hasil pengamatan dengan waktu inkubasi 2, 4, 8, 16, 24, dan 48 jam.

Kinetik degradasi bahan kering kumulatif semakin meningkat sedangkan kecepatannya semakin menurun sejalan dengan semakin lamanya waktu inkubasi. Tingkat degradasi bahan kering tertinggi dicapai pada ransum PDIN dengan tingkat kehilangan berturut-turut untuk waktu inkubasi $2,4,8,16,24$, dan 48 jam masingmasing adalah 47,$70 ; 49,48 ; 54,21 ; 56,54$; 61,58 dan $67,60 \%$, kemudian disusul oleh PDIE dan ransum PDIS. Tingkat degradasi bahan kering terendah ditemukan pada ransum PDIS dengan tingkat kehilangan berturut-turut untuk waktu inkubasi 2, 4, 8, 16, 24 , dan 48 jam masing-masing adalah 35,72 ; 36,$74 ; 41,72 ; 46,46 ; 53,36$ dan $61,94 \%$. 


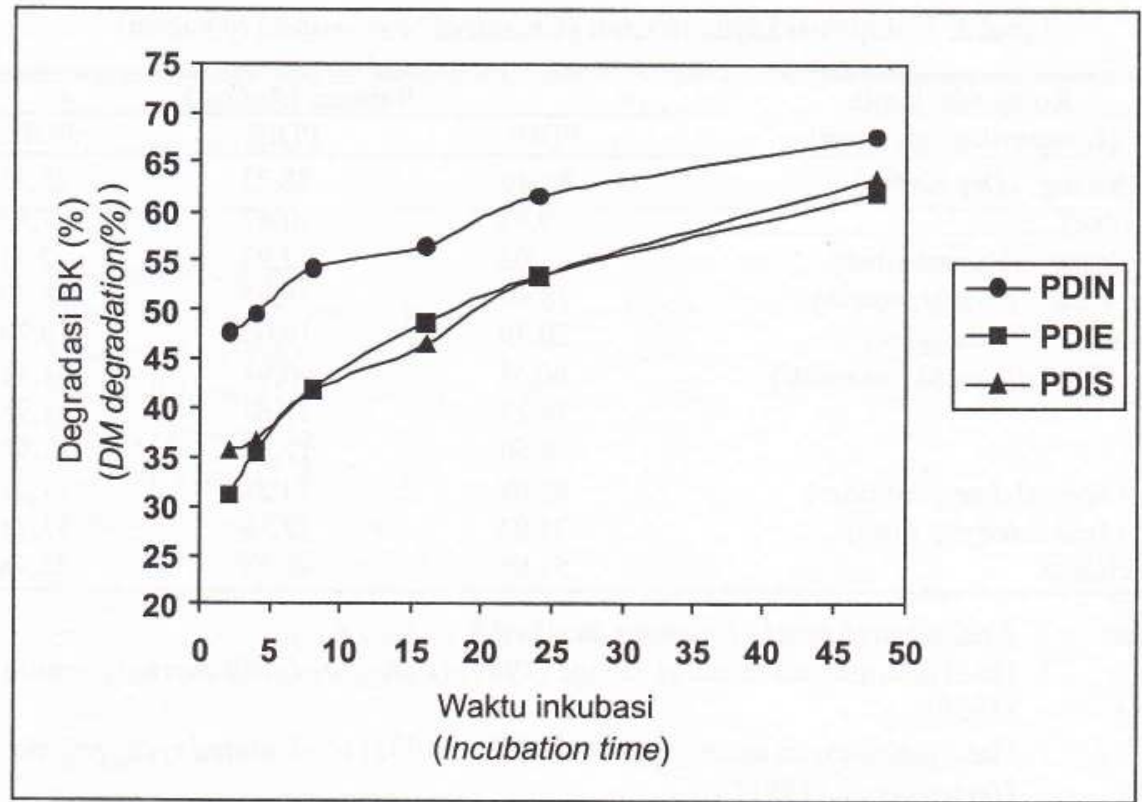

Gambar 1. Kinetik degradasi bahan kering ransum (Kinetic degradation of dry matter ration)

Tingginya nilai degradasi bahan kering pada ransum PDIN tinggi didukung dengan ketersediaan nutrien bagi mikrobia rumen selama $24 \mathrm{jam}$. Ketersediaan nutrien tersebut adalah $\mathrm{NH}_{3}(8,58 \mathrm{mmol} / 100 \mathrm{ml})$ dan VFA $(103,18 \mathrm{mmol} / \mathrm{l})$. Perkembangan mikrobia rumen diperlukan konsentrasi $\mathrm{NH}_{3}$ sekitar 2,3-13,3 mg/100ml (Blanchart 1984) yang disitasi oleh Widyobroto et al.(1995), sedangkan konsentrasi VFA rumen berkisar antara $80-160 \mathrm{mM} / 1$ (Sutardi et al., 1983). Hal ini sesuai dengan pendapat (Ørskov, (1992), yang menyatakan bahwa faktor-faktor yang mempengaruhi degradasi secara in sacco dibedakan menjadi dua faktor, yaitu faktor internal dan faktor eksternal. Faktor internal yang berpengaruh adalah konsentrasi $\mathrm{NH}_{3}$, konsentrasi VFA, $\mathrm{pH}$ rumen dan laju partikel pakan keluar dari rumen. Amonia $\left(\mathrm{NH}_{3}\right)$ dimanfaatkan oleh mikrobia rumen sebagai sumber N, sedangkan VFA digunakan sebagai sumber energi dan kerangka karbon untuk sintesis protein tubuhnya. Dengan ketersediaan nutrien yang cukup maka mikrobia rumen akan berkembang dengan pesat dan akan semakin banyak dapat mendegrasi bahan kering ransum.

Fenomena tersebut diakibatkan oleh kualitas bahan pakan penyusun konsentrat masing-masing ransum yang berbeda, hal ini tidak bisa dihindari karena untuk mendapatkan nilai PDI yang berbeda harus menggunakan bahan pakan yang berbeda. Degradasi bahan kering pada masing-masing waktu inkubasi pada bahan ransum perlakuan menunjukkan peningkatan. Hal ini menunjukkan bahwa semakin lama ransum berada dalam rumen akan semakin lama pula kesempatan mikrobia rumen untuk mendegradasi komponen ransum dalam hal ini adalah protein, lemak dan karbohidrat serta komponen ransum lain yang termasuk dalam fraksi bahan kering. Nilai rata-rata fraksi $a, b$, c dan DT degradasi bahan kering pakan perlakuan, disajikan pada Tabel 3 . 
Tabel 3. Rerata nilai degradasi fraksi a, b, c dan DT BK ransum (\%) (Average degradability of $a, b, c$ fraction and DT dry matter ration (\%))

\begin{tabular}{cccc}
\hline \hline Variabel & \multicolumn{3}{c}{ Ransum (Ration) } \\
\cline { 2 - 4 } (Variable) & PDIN & PDIE & PDIS \\
\hline Fraksi a (a fraction) & $45,47^{\mathrm{a}}$ & $29,31^{\mathrm{c}}$ & $31,79^{\mathrm{b}}$ \\
Fraksi b (b fraction) & $22,14^{\mathrm{b}}$ & $34,32^{\mathrm{a}}$ & $31,61^{\mathrm{a}}$ \\
Fraksi c (c fraction) & 5,27 & 5,04 & 4,65 \\
DT $(T D)$ & $55,75^{\mathrm{a}}$ & $44,72^{\mathrm{b}}$ & $45,42^{\mathrm{b}}$ \\
\hline
\end{tabular}

a,b,c Superskrip yang berbeda pada baris yang sama menunjukkan perbedaan nyata $(\mathrm{P}<0,05)$

(Different superscript at the same rows indicating significant differences $(P<0.05)$ )

Hasil penelitian menunjukkan bahwa fraksi a pada ransum PDIN $(45,47 \%)$ nyata lebih tinggi $(\mathrm{P}<0,05)$ dibanding PDIS (31,79\%), dan PDIE (29,31\%). Antara ransum PDIS dan PDIE juga menunjukkan perbedaan yang nyata $(\mathrm{P}<0,05)$. Hal ini menunjukkan bahwa pada ransum PDIN komponen bahan kering yang mudah terdegradasi paling tinggi dibanding ransum PDIS dan PDIE.

Hasil penelitian menunjukkan bahwa fraksi b pada ransum PDIE $(34,32 \%)$ adalah yang tertinggi disusul oleh PDIS $(31,61 \%)$, lebih tinggi dibanding PDIN $(22,14 \%)$. Antara ransum PDIS dan PDIE tidak menunjukkan perbedaan yang nyata. Hal ini menunjukkan bahwa pada ransum PDIE dan PDIS mengandung komponen bahan kering yang potensial terdegradasi lebih tinggi dibanding ransum PDIN, sedangkan fraksi c (laju degradasi fraksi b) untuk ketiga jenis ransum tidak menunjukkan perbedaan nyata.

Hasil penelitian menunjukkan bahwa nilai DT pada ransum PDIN $(55,76 \%)$ nyata lebih tinggi $(\mathrm{P}<0,05)$ dibanding pada PDIE $(45,42 \%)$ dan PDIS $(44,72 \%)$, namun demikian antara PDIE dan PDIS tidak menunjukkan perbedaan nyata. Hal ini menunjukkan bahwa pada ransum PDIN memiliki degradasi teori yang lebih tinggi dibanding pada PDIE dan PDIS. Tingginya nilai DT pada ransum PDIN disebabkan oleh fraksi a ransum tersebut lebih tinggi dibanding pada PDIE dan PDIS. Karena fraksi yang mudah terdegradasi lebih tinggi maka degradasi teori (DT) yang dihasilkan pada ransum PDIN juga lebih tinggi dibanding kedua ransum lainnya. Hal ini sesuai dengan pendapat Brewbaker et al. (1996) yang menyatakan bahwa tingginya nilai degradasi fraksi a (soluble atau mudah terdegradasi) menyebabkan tingkat kelarutan bahan pakan tersebut juga tinggi, sehingga tingkat kecernaan bahan pakan tersebut juga tinggi. Selain itu ransum PDIN merupakan ransum yang disusun dengan prekursor protein tinggi, yang diharapkan mampu mensuplai kebutuhan protein bagi mikrobia rumen, sehingga menyebabkan tingginya nilai DT pada ransum PDIN.

\section{Degradasi bahan organik ransum perlakuan secara in sacco}

Kinetik degradasi bahan organik ransum penelitian (PDIN, PDIE, dan PDIS) disajikan dalam Gambar 2. Data tersebut merupakan nilai rata-rata dari 6 hasil pengamatan dengan waktu inkubasi $2,4,8,16$, 24, dan 48 jam.

Kinetik degradasi kumulatif semakin meningkat sedangkan kecepatannya semakin menurun sejalan dengan semakin lamanya waktu inkubasi. Tingkat degradasi bahan organik tertinggi dicapai pada ransum PDIN dengan tingkat degradasi berturut-turut untuk waktu inkubasi 2, 4, 8, 16, 24, dan 48 jam adalah masing-masing 47,$35 ; 49,67 ; 54,62$; 57,$38 ; 63,38$ dan $69,88 \%$, kemudian disusul oleh ransum PDIS dan ransum PDIE. Tingkat degradasi bahan organik terendah ditemukan pada ransum PDIE dengan tingkat degradasi 
Berturut-turut untuk waktu inkubasi 2, 4, 8, 16,24 , dan 48 jam adalah masing-masing 30,$18 ; 34,37 ; 41,11 ; 49,77 ; 53,41$ dan $66,99 \%$.

Degradasi bahan organik masih mengalami peningkatan hingga waktu inkubasi selama 48 jam. Tingkat degradasi bahan organik pada masing-masing waktu inkubasi pada ransum PDIE lebih rendah dibandingkan dengan PDIS dan PDIN.

Degradasi bahan organik pada masingmasing waktu inkubasi pada bahan pakan perlakuan menunjukkan peningkatan. Hal ini menunjukkan semakin lama pakan berada dalam rumen akan memberi kesempatan mikrobia rumen untuk memanfaatkannya dalam upaya perkembangbiakan mikrobia rumen dan pada gilirannya kemampuan mendegradasi komponen pakan berserat akan meningkat. Nilai rata-rata fraksi a, b, c dan DT bahan organik pakan perlakuan, disajikan pada Tabel 4.

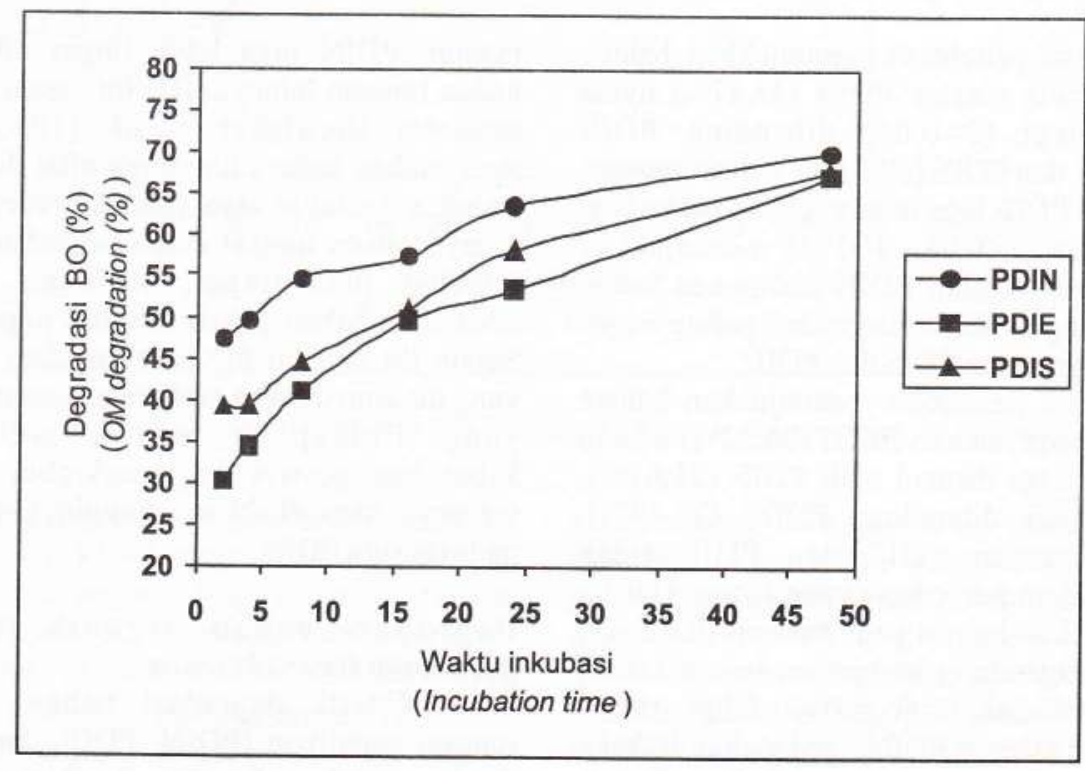

Gambar 2. Kinetik degradasi bahan organik ransum (Kinetic degradation of organic matter ration)

Tabel 4. Rerata nilai degradasi fraksi a, b, c, dan DT BO ransum (\%) (Average degradability $a, b, c$ fraction and DT organic matter ration (\%))

\begin{tabular}{lccc}
\hline \hline \multirow{2}{*}{$\begin{array}{c}\text { Variabel } \\
\text { (Variable) }\end{array}$} & RDIN & PDIE & PDIS \\
\cline { 2 - 4 } & $44,14^{\mathrm{a}}$ & $27,89^{\mathrm{b}}$ & $34,66^{\mathrm{c}}$ \\
\hline Fraksi a (a fraction) & $25,74^{\mathrm{c}}$ & $39,09^{\mathrm{a}}$ & $33,04^{\mathrm{b}}$ \\
Fraksi b (b fraction) & 5,53 & 4,75 & 4,95 \\
Fraksi c (c fraction) & $56,44^{\mathrm{a}}$ & $45,11^{\mathrm{c}}$ & $49,47^{\mathrm{b}}$ \\
DT (TD) & &
\end{tabular}

${ }^{a, b, c}$ Superskrip yang berbeda pada baris yang sama menunjukkan perbedaan nyata $(\mathrm{P}<0,05)$ (Different superscript at the same rows indicating significant differences $(P<0.05)$ ) 
Hasil penelitian menunjukkan adanya perbedaan yang nyata $(\mathrm{P}<0,05)$ fraksi $a, b$ dan DT pada bahan organik bahan ransum perlakuan, sedangkan fraksi c bahan organik pada ransum perlakuan tidak menunjukkan perbedaan yang nyata.

Hasil penelitian menunjukkan bahwa komponen bahan organik yang mudah tersedia (fraksi a) dan degradasi teori (DT) pada ransum $\mathrm{PDIN}$ nyata $(\mathrm{P}<0,05)$ lebih tinggi dibanding PDIE dan PDIS. Hal ini menunjukkan bahwa pada ransum PDIN komponen bahan organik yang mudah tersedia lebih tinggi dibanding pada PDIE dan PDIS. Nilai DT pada PDIN $(56,44 \%)$ nyata $(\mathrm{P}<0,05)$ lebih tinggi dibanding pada PDIS $(49,47 \%)$ dan PDIE $(45,11 \%)$. Hal ini menunjukkan bahwa pada PDIN memiliki degradasi teori yang lebih tinggi dibanding pada PDIE dan PDIS. Tingginya nilai DT pada PDIN disebabkan oleh fraksi a pada bahan pakan tersebut lebih tinggi dibanding pada PDIE dan PDIS. Karena fraksi yang mudah terdegradasi lebih tinggi maka degradasi teori yang dihasilkan pada ransum PDIN lebih tinggi dibanding kedua pakan lainnya. Tingginya nilai DT bahan organik pada ransum PDIN berkaitan dengan kandungan rumen degradable protein (RDP) yang lebih rendah dibanding PDIE dan PDIS. Dengan tingginya RDP akan memberikan nutrien bagi mikrobia rumen untuk berkembang biak dan dapat mencerna nutrien yang masuk dalam rumen, sehingga degradasi teori pada ransum PDIN menjadi lebih tinggi dibanding PDIE dan PDIS. Dijkstra (1994) menyatakan bahwa degradasi protein juga berperan untuk menghasilkan VFA, methan dan amonia. Kuantitas protein dan degradable protein yang tersedia akan mengubah rasio karbohidrat terfermentasi atau secara langsung berhubungan dengan biomas mikroba. Hal ini didukung Mansfield et al. (1993) bahwa menurunnya RDP dalam ransum menurunkan produksi VFA., hal ini disebabkan menurunnya proteolisis dan kurangnya deaminasi oksidatif dari protein pakan.
Nilai degradasi teori bahan organik jerami padi sebagai pakan basal yang diformulasi berdasarkan PDIN, PDIE maupun PDIS $(56,44 ; 45,11$ dan $49,47 \%)$ lebih tinggi dibandiing nilai DT BO jerami padi $40,54 \%$ (Budhi et al., 2000). Hal ini menunjukkan bahwa pemanfaatan jerami padi menjadi lebih meningkat dengan diterapkannya formulasi berdasarkan sistem PDI.

\section{Degradasi protein kasar ransum perlakuan secara in sacco}

Kinetik degradasi protein kasar ransum penelitian (PDIN, PDIE dan PDIS) disajikan dalam Gambar 3. Data tersebut merupakan nilai rata-rata dari 6 hasil pengamatan dengan waktu inkubasi 2, 4, 8, 16, 24 dan 48 jam.

Kinetik degradasi kumulatif semakin meningkat sedangkan kecepatannya semakin menurun sejalan dengan semakin lamanya waktu inkubasi. Tingkat degradasi protein kasar tertinggi dicapai pada ransum PDIN dengan tingkat degradasi berturut-turut untuk waktu inkubasi $2,4,8,16,24$ dan 48 jam adalah masing-masing 68,$26 ; 68,78 ; 73,53$; 73,$64 ; 77,66$ dan $80,98 \%$, kemudian disusul oleh PDIS dan PDIE. Tingkat degradasi protein kasar terendah ditemukan pada ransum PDIE dengan tingkat degradasi berturut-turut untuk waktu inkubasi $2,4,8,16$, 24 dan 48 jam adalah masing-masing 36,10 ; 40,$49 ; 46,47 ; 53,59 ; 57,18$ dan $62,82 \%$. Degradasi protein kasar masih mengalami peningkatan hingga waktu inkubasi selama 48 jam. Tingkat degradasi protein kasar pada masing-masing waktu inkubasi pada ransum PDIE lebih rendah dibandingkan dengan PDIS dan PDIN.

Degradasi protein kasar pada masingmasing waktu inkubasi pada bahan pakan perlakuan menunjukkan peningkatan. $\mathrm{Hal}$ ini menunjukkan semakin lama pakan berada dalam rumen akan memberi kesempatan mikrobia rumen untuk memanfaatkannya dalam upaya perkembangbiakan mikrobia rumen dan pada gilirannya kemampuan mendegradasi komponen pakan berserat akan meningkat. Nilai rata-rata fraksi a, b, c dan DT 
bahan organik pakan perlakuan, disajikan pada Tabel 5 .

Hasil analisis variansi menunjukkan adanya perbedaan yang nyata $(\mathrm{P}<0,05)$ fraksi $\mathrm{a}$, b dan DT pada protein kasar ransum perlakuan, sedangkan fraksi c protein kasar pada ransum perlakuan tidak menunjukkan perbedaan yang nyata..

Hasil penelitian menunjukkan bahwa komponen bahan organik yang mudah tersedia (fraksi a) dan degradasi teori (DT) pada ransum $P D I N$ nyata $(P<0,05)$ lebih tinggi dibanding PDIE dan. PDIS. Fraksi potensial terdegradasi (b) dan laju degradasi fraksi b (c) pada ransum $P D I E$ nyata $(P<0,05)$ lebih tinggi dibanding pada PDIN dan PDIS, sedangkan antara PDIN dan PDIS tidak menunjukkan perbedaan nyata. Hal ini menunjukkan bahwa pada ransum PDIN mengandung protein kasar yang mudah tersedia dibanding pada ransum PDIE dan PDIS.

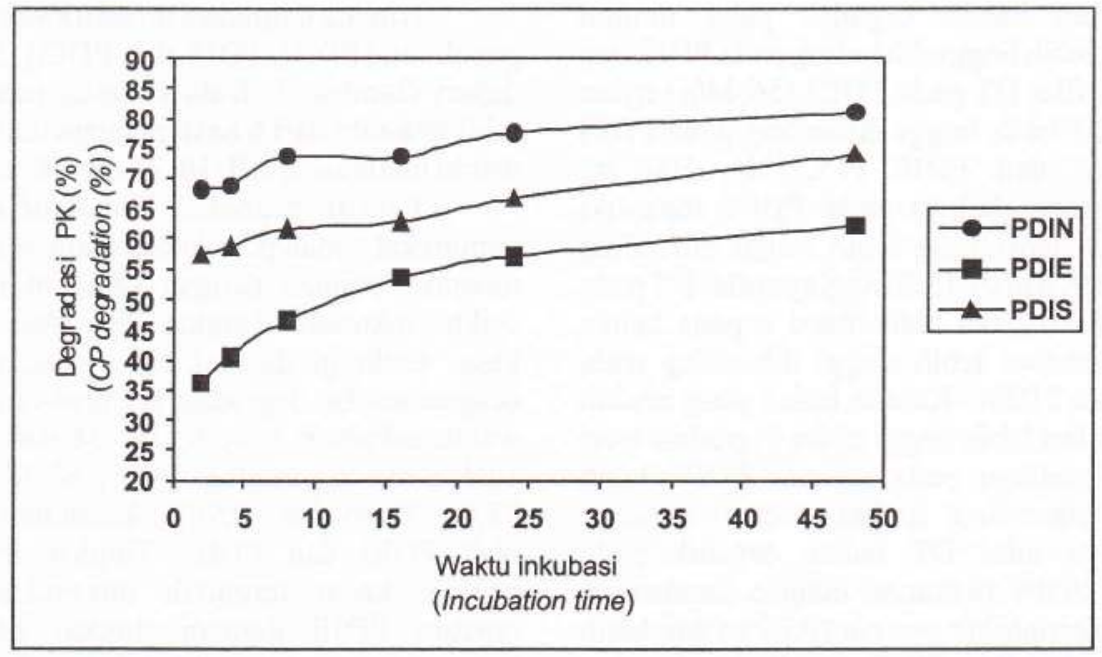

Gambar 3. Kinetik degradasi protein kasar ransum (Kinetic degradation of crude protein ration)

Tabel 5. Rerata nilai degradasi fraksi a, b, c, dan DT PK ransum (\%) (Average degradability $a, b, c$ fraction and $D T$ of crude protein ration (\%))

\begin{tabular}{crcc}
\hline \hline $\begin{array}{c}\text { Variabel } \\
\text { (Variable) }\end{array}$ & \multicolumn{3}{c}{ Ransum (Ration) } \\
\cline { 2 - 4 } & PDIN & PDIE & PDIS \\
\hline Fraksi a (a fraction) & $65,87^{\mathrm{a}}$ & $32,40^{\mathrm{c}}$ & $55,70^{\mathrm{b}}$ \\
Fraksi b (b fraction) & $15,10^{\mathrm{b}}$ & $30,42^{\mathrm{a}}$ & $18,30^{\mathrm{b}}$ \\
Fraksi c (c fraction) & $6,03^{\mathrm{b}}$ & $7,84^{\mathrm{a}}$ & $3,81^{\mathrm{c}}$ \\
DT (TD) & $73,50^{\mathrm{a}}$ & $49,57^{\mathrm{c}}$ & $62,80^{\mathrm{b}}$ \\
\hline
\end{tabular}

a,b,c Superskrip yang berbeda pada baris yang sama menunjukkan perbedaan nyata $(\mathrm{P}<0,05)$

(Different superscript at the same rows indicating significant differences $(P<0.05)$ ) 
Hasil penelitian menunjukkan bahwa nilai DT pada ransum PDIN $(73,35 \%)$ nyata $(\mathrm{P}<0,05)$ lebih tinggi dibanding pada PDIS $(62,80 \%)$ dan PDIE $(49,57 \%)$. Hal ini menunjukkan bahwa pada ransum PDIN memiliki degradasi teori yang lebih tinggi dibanding pada ransum PDIE dan PDIS. Tingginya nilai DT pada ransum PDIN disebabkan oleh fraksi a (mudah terdegradasi) pada ransum tersebut lebih tinggi dibanding pada PDIE dan PDIS. Karena fraksi yang mudah terdegradasi lebih tinggi maka degradasi teori yang dihasilkan pada ransum PDIN lebih tinggi dibanding kedua pakan lainnya. Tingginya fraksi a dan nilai DT protein kasar pada ransum PDIN berkaitan dengan kandungan degradable protein yang lebih tinggi dibanding ransum PDIE dan PDIS. Hal ini mendukung hasil penelitian Nuswantara et al. (2005), bahwa tingginya kecernaan protein pada ransum PDIN tinggi diduga berkaitan dengan kandungan protein kasar dan tingkat degradabilitas protein bahan pakan penyusun ransumnya. Ransum PDIN tinggi tersusun atas bahan pakan dengan kandungan protein kasar dan tingkat degradabilitas yang tinggi. Tingginya degradabilitas protein ransum mengakibatkan ketersediaan prekursor $\mathrm{N}$ dalam rumen untuk sintesis protein mikrobia juga tinggi. Namun demikian pada ransum ini juga memiliki undegraded protein (UDP) yang tinggi, sehingga protein pakan yang lolos dari degradasi oleh mikrobia rumen dan dapat dicerna dalam intestinum juga tinggi. Aras protein kasar dapat mempengaruhi kecernaan pakan, peningkatan kecernaan protein kasar akan memberikan nutrien esensial lebih banyak untuk mikrobia rumen (Widyobroto et al., 1994). Selanjutnya dinyatakan bahwa jika pakan yang kaya akan protein ditambahkan untuk mengimbangi hijauan yang rendah proteinnya, maka aktivitas mikrobia dalam mendegradasi pakan akan meningkat.

Nilai degradasi teori protein kasar jerami padi sebagai pakan basal yang diformulasi berdasarkan PDIN, PDIE maupun PDIS cukup tinggi yaitu 56,$44 ; 45,11$ dan
$49,47 \%$, hal ini menunjukkan bahwa pemanfaatan jerami padi menjadi lebih meningkat dengan diterapkannya formulasi berdasarkan sistem PDI.

\section{Kesimpulan}

Berdasarkan hasil penelitian dapat disimpulkan bahwa degradasi teori (DT) pada ransum dengan pakan basal jerami padi yang diformulasi berdasarkan ketersediaan prekursor nitrogen tinggi (PDIN) lebih tinggi dibanding yang diformulasi berdasarkan ketersediaan prekursor energi tinggi maupun protein dan energi yang seimbang.

\section{Ucapan Terima Kasih}

Ucapan terima kasih kami sampaikan kepada Direktur Proyek Peningkatan Penelitian dan Pengembangan pada Masyarakat (P4M)Direktorat Jenderal Perguruan Tinggi Departemen Pendidikan Nasional Republik Indonesia, melalu Proyek Hibah Penelitian Tim Pascasarjana dengan nomor kontrak 066/P4T/DPPM/HPTP/III/ 2004 yang telah membiayai penelitian ini. Ucapan terima kasih juga disampaikan pada teman-teman Tim penelitian HPTP baik S-1, S-2 maupun S-3 atas kerjasamanya dalam menyelesaikan penelitian ini.

\section{Daftar Pustaka}

AOAC. 1975. Offical Methods of Analysis. $12^{\text {th }}$ ed. Association of Official Analitical Chemist. Washington D.C.

Astuti, M. 1981. Rancangan Percobaan dan Analisis Statistik Bagian II. Bagian Pemuliaan Ternak Fakultas Peternakan Universitas Gadjah Mada. Yogyakarta. (tidak diterbitkan).

Brewbaker. J., P. Cheeke, N. Glover, C. Hughes, D. Kass, M. Kass, B.Seibert, J. Stewart, J. Sumberg, and F. Wiersum. 1996. Glirisidia : Produksi dan Manfaat (Diterjemahkan oleh Emmanuel Keffi). Asia-Pasific 
Agroforestry Network Secretariat (APAN), Bogor.

Budhi. S.P.S., S. Reksohadiprodjo., E.R. Ørskov, B.P. Widyobroto, dan M. Soejono. 2000. New Concept of Fibrous Feed Evaluation in the Tropics. Final Report Graduate Team Research Grant University Research for Graduate Education (URGE). Faculty of animal Science Gadjah Mada University. Yogyakarta .

Dhanoa, M.S. 1988. On the analysis of dacron bag data for low degradability feeds. Grass and Forage Sci. 43:441444.

Dijkstra, J. 1994. Production and absorbsion of volatile fatty acids in the rumen. Livest. prod. Sci. 39:61 -69.

Hartadi, H., S. Reksohadiprodjo, dan A.D. Tillman. 1997. Tabel Komposisi Pakan Ternak untuk Indonesia. Cetakan keempat. Gadjah Mada University Press.

Jarrige, R. 1989. Ruminant Nutrition. INRA. Paris.

Leng, R.A. 1980. Principle and Practice of Feeding Tropical Crop and by Products to Ruminant. Department of Biochemistry and Nutrition University of New England. Armidale, Australia

Mc Donald. P, R.A. Edwards and S.F.D. Greenhalgh. 1988. Animal Nutrition. $4^{\text {th }}$ Ed. Longman, London.

Mehrez,A.Z. and E.R. Ørskov. 1977. Astudy of the artificial fibre bag technique for determining the digestibility of feed in the rumen. J. Agric. Sci. Camb. 88: 645-650.

Nuswantara, L.K., M. Soejono, R. Utomo dan B.P. Widyobroto. 2005 Pengaruh Ransum Prekursor Nitrogen Tinggi dan Energi Tinggi terhadap Kecernaan Nutrien Sapi Perah dengan Pakan Basal Jerami Padi. Jurnal Pengembangan Peternakan Tropis Vol 30. No 3 September 2005. pp : 175 178.

Ørskov, E. R. and I. Mc Donald. 1979. The estimation of protein degradability in the rumen from incubation measurements weighted according to rate of passage. J. Agric. Sci., Camb. 92: 499-503.

Ørskov, E.R. 1992. Protein Nutrition in Ruminant. Academic Press. London.

Soejono, M. 1990. Petunjuk Laboratorium Analisis dan Evaluasi Pakan. Fakultas Peternakan Universitas Gadjah Mada. Yogyakarta.

Soejono M., B. P. Widyobroto, R. Utomo dan A. Agus. 1998. Standarisasi Pengukuran Degradasi In sacco di Indonesia. Laporan Penelitian Hibah Bersaing VII Perguruan Tinggi. Fakultas Peternakan UGM.

Sutrisno, C.I. 2002. Peran Teknologi Pengolahan Limbah Pertanian dalam Pengembangan Ternak Ruminansia. Pidato Pengukuhan pada Upacara Penerimaan Jabatan Guru Besar dalam Ilmu Makanan Ternak pada Fakultas Peternakan Universitas Diponegoro. Semarang.

Sutardi, T., N.A. Sigit dan T. Toharmat. 1983. Standarisasi Mutu Protein Bahan Makanan Ternak Ruminansia, B erdasarkan Parameter Metabolismenya oleh Mikrobia Rumen. Proyek Pengembangan Ilmu dan Teknologi. Ditjen Pendidikan Tinggi. Jakarta.

Utomo, R. 2001. Penggunaan Jerami Padi sebagai Pakan Basal: Suplementasi Sumber Energi dan Protein terhadap Transit Partikel Pakan, Sintesis Protein Mikrobia, Kecernaan, dan Kinerja Sapi Potong. Disertasi. Program Pascasarjana Universitas Gadjah Mada. Yogyakarta.

Widyobroto B.P., S. Padmowijoto, dan R. Utomo. 1997 Pendugaan kualitas protein 60 bahan pakan untuk ternak ruminansia. Laporan Penelitian. Fakultas Peternakan UGM, Yogyakarta.

Widyobroto, B.P., S. Padmowijoto dan R. Utomo. 1994. Pendugaan kualitas protein bahan pakan (hijauan, 
konsentrat dan limbah pertanian) untuk ternak ruminansia. Laporan Penelitian Hibah Bersaing Perguruan Tinggi II/2. Departemen Pendidikan dan Kebudayaan RI., Jakarta.
Widyobroto BP., S. Padmowijoto, R. Utomo and M. Soejono. 1995 In sacco degradation of eight tropical forages. Ann. Zootch. 44(Suppl), 194. 